\title{
PROCESSAMENTO DE PILHAS DO TIPO BOTÃO
}

Cristiano Nunes da Silva e Julio Carlos Afonso*

Departamento de Química Analítica, Instituto de Química, Universidade Federal do Rio de Janeiro, Av. Athos da Silveira Ramos, 149, Bloco A, 21941-909 Rio de Janeiro - RJ, Brasil

Recebido em 2/5/07; aceito em 11/1/08; publicado na web em 13/8/08

PROCESSING OF SPENT BUTTON CELLS. This work presents hydrometallurgical routes for recovering valuable elements from spent button cells, based on leaching of internal components with sulfuric acid ( $\mathrm{Li} / \mathrm{MnO}_{2}$ and $\mathrm{Zn}$-air) or nitric acid $(\mathrm{Ag}-\mathrm{Zn})$, at $90{ }^{\circ} \mathrm{C}$ for $2 \mathrm{~h}$. Slow evaporation of the leachate crystallized $\mathrm{MnSO}_{4} \cdot \mathrm{H}_{2} \mathrm{O}$, whereas lithium was partially recovered as LiF. Mercury present in $\mathrm{Zn}$-air and $\mathrm{Ag}-\mathrm{Zn}$ samples was precipitated as $\mathrm{HgS}$. Silver was recovered as $\mathrm{AgCl}$ before mercury precipitation. Zinc and iron were precipitated as hydroxides. The amount of iron varied according to the intensity of the corrosion of the external cell case. Final wastes are neutral and colorless sodium sulfate/nitrate solutions.

Keywords: button cell; metal recovery; waste management.

\section{INTRODUÇÃO}

As pilhas do formato botão são assim denominadas devido à geometria do produto; de formato cilíndrico, seu diâmetro de seção reta pode chegar a $25 \mathrm{~mm}$, enquanto que a altura (espessura) varia de menos de 1 até $15 \mathrm{~mm} .{ }^{1}$ Esse formato compacto permite a inserção em aparelhos pequenos e portáteis. Suas principais aplicações são em aparelhos para surdez, calculadoras eletrônicas, relógios de pulso digitais, agendas eletrônicas e sistemas de alarme e de segurança. Apesar desse amplo emprego, dados da European Portable Battery Association (EPBA) ${ }^{2}$ mostram que elas detiveram apenas $0,4 \%$ do mercado consumidor europeu em 2003 (610,8 t consumidas, contra $373 \mathrm{t} \mathrm{em} \mathrm{2000).} \mathrm{Na} \mathrm{Índia,} \mathrm{a} \mathrm{fatia} \mathrm{do} \mathrm{mercado} \mathrm{atinge}$ cerca de $3 \% .^{3}$ No Brasil, não se tem dados precisos.

Existem vários tipos de sistemas eletroquímicos nas pilhas botão: zinco-ar (Zn-ar), óxido de prata-zinco (Ag-Zn), óxido de mercúrio (em desuso) e lítio-dióxido de manganês $\left(\mathrm{Li} / \mathrm{MnO}_{2}\right)$. Exceto esta última, que utiliza solvente não aquoso devido à reatividade do lítio metálico com água, as demais empregam meio aquoso contendo base forte $(\mathrm{NaOH} / \mathrm{KOH})$ como eletrólito.

A comercialização da pilha $\mathrm{Zn}$-ar é feita com o produto selado; após a remoção do selo (plástico), o produto é ativado pela difusão do oxigênio atmosférico dentro do produto. ${ }^{3,4}$ Seu potencial é de cerca de $1,6 \mathrm{~V}$ à temperatura ambiente. Nela se tem as seguintes reações: ${ }^{3}$

No catodo: $\mathrm{O}_{2}+2 \mathrm{H}_{2} \mathrm{O}+4 \mathrm{e}^{-} \longrightarrow 4 \mathrm{OH}^{-}$

No anodo: $2 \mathrm{Zn} \longrightarrow 2 \mathrm{Zn}^{2+}+4 \mathrm{e}^{-}$

$$
2 \mathrm{Zn}^{2+}+4 \mathrm{OH}^{-} \longrightarrow 2 \mathrm{Zn}(\mathrm{OH})_{2}
$$

Reação global: $2 \mathrm{Zn}+\mathrm{O}_{2}+2 \mathrm{H}_{2} \mathrm{O} \longrightarrow 2 \mathrm{Zn}(\mathrm{OH})_{2}$

Podem ocorrer reações paralelas com geração de gás hidrogênio devido à corrosão do zinco, especialmente aquele com pureza abaixo do grau eletrolítico, ${ }^{5}$ com risco de ruptura do produto e explosão por ignição do gás:

$\mathrm{Zn}+2 \mathrm{H}_{2} \mathrm{O} \longrightarrow \mathrm{Zn}(\mathrm{OH})_{2}+\mathrm{H}_{2}$
Esse é um dos motivos que levam à adição de mercúrio ao ano$\mathrm{do}^{5}$ (ele forma um amálgama com o zinco). O hidróxido de zinco se deposita no anodo, mas pode eventualmente se dissolver em excesso local de base forte $(\mathrm{pH}>13):^{3}$

$\mathrm{Zn}(\mathrm{OH})_{2}+2 \mathrm{OH}^{-} \rightleftarrows \mathrm{Zn}(\mathrm{OH})_{4}^{2-}$

A pilha Ag-Zn é bastante empregada na área militar (submarinos, torpedos, mísseis) devido à sua alta densidade de energia e de potência, ${ }^{5-7}$ sendo adequada também para sistemas compactos $^{8} \mathrm{e}$ aqueles que requerem liberação instantânea (pulso) de energia. ${ }^{7}$ Ela apresenta baixíssima taxa de auto-descarga. ${ }^{6,8}$ Além do modelo de uso único, existe também a versão recarregável. ${ }^{6} \mathrm{O}$ potencial desta pilha é de cerca de $1,6 \mathrm{~V}$ à temperatura ambiente. As reações que ocorrem nesse sistema são: ${ }^{9}$

No catodo: $\mathrm{Ag}_{2} \mathrm{O}+\mathrm{H}_{2} \mathrm{O}+2 \mathrm{e}^{-} \longrightarrow 2 \mathrm{Ag}+2 \mathrm{OH}^{-}$

No anodo: $\mathrm{Zn} \longrightarrow \mathrm{Zn}^{2+}+2 \mathrm{e}^{-}$

$$
\mathrm{Zn}^{2+}+2 \mathrm{OH}^{-} \longrightarrow \mathrm{Zn}(\mathrm{OH})_{2}
$$

Reação global: $\mathrm{Zn}+\mathrm{Ag}_{2} \mathrm{O}+\mathrm{H}_{2} \mathrm{O} \longrightarrow 2 \mathrm{Ag}+\mathrm{Zn}(\mathrm{OH})_{2}$

Apesar do catodo ser comumente referido como $\operatorname{Ag}_{2} \mathrm{O}$, pode na verdade ocorrer uma mistura de prata metálica e dos óxidos $\mathrm{Ag}_{2} \mathrm{O}$ e $\mathrm{AgO}$, decorrente do método de obtenção do catodo (oxidação eletrolítica da prata). ${ }^{5} \mathrm{O}$ anodo (zinco de alta pureza) normalmente é obtido via processo eletrolítico em meio alcalino. ${ }^{5}$

Da mesma forma como na pilha $\mathrm{Zn}$-ar, pode haver a corrosão do zinco com liberação de gás hidrogênio, e a solubilização do hidróxido em excesso local de base. A redeposição em local diferente do ponto onde foi gerado ${ }^{6}$ leva à limitação do número de ciclos do modelo recarregável (até cerca de 100 recargas) e da vida útil do produto (máximo 2-3 anos), por conta da deformação do anodo no topo e nas partes laterais, reduzindo a capacidade de recarga do sistema.

As pilhas $\mathrm{Li} / \mathrm{MnO}_{2}$ apresentam um potencial em torno de 3,0 V à temperatura ambiente. As reações nesse sistema são: $:^{9,10}$

No anodo: $\mathrm{Li} \longrightarrow \mathrm{Li}^{+}+\mathrm{e}^{-}$ 
No catodo: $\mathrm{MnO}_{2}+\mathrm{Li}^{+}+\mathrm{e}^{-} \longrightarrow \mathrm{LiMnO}_{2}$

Apesar da pequena participação no cômputo do mercado mundial da energia portátil, a maioria dos tipos de pilhas botão existentes apresenta riscos ambientais devido à presença de mercúrio. A legislação norte-americana prevê a coleta obrigatória das pilhas e baterias que contêm este elemento, evitando que venham a ser descartadas juntamente com o lixo urbano em aterros sanitários comuns. ${ }^{11}$ Mesmo assim, estima-se que cerca de $88 \% \mathrm{~m} / \mathrm{m}$ do mercúrio (e $50 \% \mathrm{~m} / \mathrm{m}$ do cádmio) presentes em aterros municipais provenham do descarte inadequado de pilhas e baterias usadas, bem como de dispositivos eletroeletrônicos que os contêm embutidos. ${ }^{12} \mathrm{Na}$ Europa, cerca de $45 \%$ dos equipamentos portáteis contendo baterias e pilhas embutidas vão para aterros ou incineradores, o que significa liberação de poluentes para a atmosfera, solo e recursos hídricos. ${ }^{13} \mathrm{~A}$ pressão de vapor do mercúrio metálico $\left(0,0012 \mathrm{~mm} \mathrm{Hg}\right.$ a $25^{\circ} \mathrm{C}$ e $\left.1 \mathrm{~atm}\right)$ dá uma concentração superior ao limite de exposição ocupacional previsto pela norma regulamentadora $\mathrm{n}^{\circ} 15$ (NR-15) do Ministério do Trabalho e do Emprego (Quadro I do Anexo 1 - 0,04 $\mathrm{mg} \mathrm{m}^{-3}$ para uma jornada de até $48 \mathrm{~h}$ semanais $\left.{ }^{14}\right)$. A tendência com a evolução da tecnologia da energia portátil é o banimento do mercúrio (e do cádmio) das formulações de pilhas e baterias.

De fato, observa-se que pilhas e baterias à base de lítio vêm substituindo os sistemas tradicionais do tipo botão em muitas de suas aplicações, muito embora os sistemas Zn-ar e Ag-Zn sejam tecnologias bem mais maduras e conhecidas. ${ }^{7}$ A grande vantagem, em termos ambientais, é a ausência de metais pesados reconhecidamente danosos à saúde, como mercúrio, cádmio e chumbo. Porém, os perigos relativos à pilha $\mathrm{Li} / \mathrm{MnO}_{2}$ são de outra natureza: após a corrosão do invólucro externo, libera-se o solvente não aquoso, o qual é inflamável e tóxico (provoca dores de cabeça); o lítio metálico não reagido, em contato com água e umidade do ar, desprende calor e gás inflamável (hidrogênio), podendo levar à ignição do produto descartado. A presença de voltagem residual no produto usado é um problema, pois significa a presença de lítio metálico. O ideal seria a descarga total desse produto antes do descarte. ${ }^{15}$ Essas características tornam a disposição final inadequada e até mesmo a reciclagem uma operação de risco em função da possibilidade de fogo e explosão. Tentativas de abrí-las sem cuidados com a segurança podem expor a pilha à umidade do ar, provocando reações violentas, curto-circuito entre seus componentes e a ignição do solvente. ${ }^{16}$

No Brasil, as resoluções 257 e 263/99 do Conselho Nacional do Meio Ambiente (CONAMA) ${ }^{17}$ indicam que, desde 2001, as pilhas do tipo botão que contiverem mais que $25 \mathrm{mg}$ de mercúrio em sua formulação por unidade devem ser devolvidas ao fabricante, importador ou rede comercial para que seja dada uma destinação final correta. A Associação Brasileira da Indústria Elétrica e Eletroeletrônica (ABINEE) indica que tais pilhas, contudo, podem ser dispostas no lixo domiciliar por não excederem o teor limite permitido de mercúrio nesses produtos. ${ }^{18}$

Atualmente, a Resolução 257/99 está sob revisão, buscando compatibilizar aspectos legais acerca da coleta e destinação de pilhas e baterias que contenham chumbo, cádmio e mercúrio. ${ }^{17} \mathrm{O}$ novo texto proposto pretende ampliar o número de produtos a serem obrigatoriamente coletados pelos fabricantes e comerciantes, ao reduzir os percentuais considerados toleráveis no ambiente daqueles elementos químicos na composição dos mesmos. A partir de julho 2009, deverá ser recolhida toda pilha e bateria com teores acima de $0,0005 \% \mathrm{~m} / \mathrm{m}$ de mercúrio, $0,002 \% \mathrm{~m} / \mathrm{m}$ de cádmio, e $0,10 \% \mathrm{~m} / \mathrm{m}$ de chumbo, além daqueles com sistemas eletroquímicos chumbo-ácido, níquel-cádmio e óxido de mercúrio, e pilhas do tipo botão com teores de mercúrio acima de $2 \%$ em massa. Foi também proposta a proibição da adição de mercúrio e cádmio no processo de fabricação de pilhas do tipo zinco-manganês (comuns e alcalinas).
É curioso mencionar que existem estudos envolvendo intoxicação pela ingestão, introdução no canal auditivo e no septo nasal de pilhas do tipo botão por crianças, ${ }^{19-23}$ realizadas por pesquisadores europeus e norte-americanos, com registro de casos desde a década de $60 .{ }^{19-21}$ Isso se explica pelo pequeno tamanho dessas pilhas, que permite que sejam deglutidas com menor risco de sufocamento ou retenção no trato respiratório, como acontece com as pilhas comuns (do tipo AAA ou AA). ${ }^{20,21,23}$ Os efeitos clínicos dependem da composição química do produto, voltagem residual e do tempo de contato com o corpo (membranas, mucosas etc.). ${ }^{20} \mathrm{O}$ risco maior é a liberação dos componentes internos por corrosão do invólucro, provocando queimaduras $\left(2^{\circ}\right.$ e $3^{\circ}$ graus, perfuração da membrana/ mucosa e introdução de metais pesados no organismo). ${ }^{21}$ Testes in vitro com suco gástrico "sintético" $\left(\mathrm{HCl} 0,10-0,15 \mathrm{~mol} \mathrm{~L}^{-1}\right)^{22,23}$ ou in vivo (com cães) ${ }^{23}$ à temperatura de $\sim 37^{\circ} \mathrm{C}$, mostraram que, após $4 \mathrm{~h}$, ocorreu liberação de metais pesados, ainda que na escala de micro a nanograma; os modelos Zn-ar e Ag-Zn são os que tiveram maior liberação de componentes internos.

Quanto à gestão de pilhas e baterias usadas, os fabricantes argumentam que as únicas pilhas do tipo botão passíveis de reciclagem são as de $\mathrm{Ag}-\mathrm{Zn}$, onde o valor agregado e teor de prata elevados justificam o investimento. ${ }^{13,24} \mathrm{~A}$ literatura é extremamente escassa em trabalhos sobre o processamento de pilhas do tipo botão usadas, em contraste com o que ocorre com as baterias níquel hidretometálico (Ni-MH), níquel-cádmio ( $\mathrm{Ni}-\mathrm{Cd})$, íon lítio e até mesmo as pilhas alcalinas comuns, que vêm recebendo bastante atenção nos últimos 4 anos. Os poucos trabalhos parecem versar sobre a reciclagem de pilhas Ag-Zn. Os processos pirometalúrgicos e de cementação geram grandes quantidades de resíduos finais poluentes, têm alto consumo energético e nível de recuperação e pureza do produto final de prata nem sempre satisfatórios. ${ }^{9}$ Os processos de natureza hidrometalúrgica citados empregam ácido nítrico 10 mol L ${ }^{-1}$ (a concentração mínima ${ }^{25}$ deste ácido para dissolver a prata elementar é $8 \mathrm{~mol} \mathrm{~L}^{-1}$ ), e mesmo assim os autores ${ }^{9}$ apenas se preocuparam com a recuperação desse metal, não sendo feita uma análise acerca da gestão de resíduos de processo e do destino final do mercúrio e do zinco presentes.

Este trabalho apresenta um estudo do processamento de vários modelos de pilhas do tipo botão, visando recuperar os elementos presentes. Também foi dada atenção à questão da gestão dos resíduos gerados nos processos aplicados, assunto pouco abordado na literatura. Com base na tendência atual da literatura no processamento de pilhas e baterias usadas, serão empregados métodos hidrometalúrgicos, seguido de fracionamento da lixívia obtida, por representarem condições de trabalho mais brandas que aquelas das tradicionais rotas pirometalúrgicas.

\section{PARTE EXPERIMENTAL}

\section{Descrição e abertura das pilhas}

Foram empregadas 30 pilhas do tipo botão de diferentes marcas comerciais, fabricadas entre 1999 e 2004 , com potencial residual inferior a $0,1 \mathrm{~V}$. Oito delas tinham como componentes ativos os do sistema $\mathrm{Li} / \mathrm{MnO}_{2}$, já estudado em nosso laboratório quando do processamento de pilhas de câmeras digitais. ${ }^{26}$ As demais correspondem a pilhas Ag-Zn (4) e Zn-ar (18 amostras).

As massas das pilhas inteiras foram determinadas por meio de balança analítica. Elas foram desmontadas com o auxílio de um torno e uma pequena serra, para o rompimento do invólucro de aço, e posterior separação manual dos componentes. Todo o procedimento foi realizado com equipamento de segurança adequado, para evitar contato com as substâncias tóxicas presentes. Quando do seu pro- 
cessamento, a pilha $\mathrm{Li} / \mathrm{MnO}_{2}$ foi colocada, após aberta, em sistema de vácuo por 20 min para coleta do solvente não aquoso presente em frasco imerso em gelo picado e sal. Os componentes separados foram identificados e pesados.

\section{Processamento do conteúdo interno (catodo + anodo + eletrólito + separador)}

A abertura se deu por digestão ácida, com ácidos inorgânicos: pilhas $\mathrm{Zn}$-ar e $\mathrm{Li} / \mathrm{MnO}_{2}: \mathrm{H}_{2} \mathrm{SO}_{4} 9 \mathrm{~mol} \mathrm{~L}^{-1}\left(5 \mathrm{~mL}\right.$ solução $\mathrm{g}^{-1}$ componentes internos);

pilha Ag-Zn: $\mathrm{HNO}_{3} 10 \mathrm{~mol} \mathrm{~L}-1$ (5 mL solução $\mathrm{g}^{-1}$ componentes internos).

O ácido sulfúrico não tem efeito sobre a prata metálica, por isso a pilha $\mathrm{Ag}-\mathrm{Zn}$ foi tratada com ácido nítrico. ${ }^{25} \mathrm{Ambos}$ os procedimentos foram efetuados a $90-100{ }^{\circ} \mathrm{C}$, sob agitação constante (200 rpm), em capela. Quando do processamento da pilha $\mathrm{Li} / \mathrm{MnO}_{2}$, adicionou-se periodicamente $1 \mathrm{~mL}$ de $\mathrm{H}_{2} \mathrm{O}_{2}(30 \% \mathrm{~m} / \mathrm{m})$ a fim de converter todo o manganês ao número de oxidação +2 . Após $2 \mathrm{~h}$ o material insolúvel (sólido preto) foi isolado por filtração, lavado com água até $\mathrm{pH} 7$ $\left(10 \mathrm{~mL} \mathrm{~g}^{-1}\right)$, seco em estufa a $110^{\circ} \mathrm{C}$ por $2 \mathrm{~h}$ e pesado. É importante salientar que não foi feita a calcinação prévia do conteúdo interno das pilhas devido à presença do mercúrio em várias das amostras, o qual seria liberado para o ambiente laboratorial no referido procedimento.

O fracionamento dos metais presentes em solução dependeu do tipo de pilha processada:

pilha $\mathrm{Li} / \mathrm{MnO}_{2}$ : a evaporação lenta da solução a $90{ }^{\circ} \mathrm{C}$ resultou na formação de cristais branco-acinzentados, correspondendo a $\mathrm{MnSO}_{4}$. $\mathrm{H}_{2} \mathrm{O}$, que foram isolados por filtração, lavados com etanol $(5 \mathrm{~mL}$ $\left.\mathrm{g}^{-1}\right)$, secos ao ar e pesados. No líquido ácido residual, adicionou-se solução saturada de fluoreto de potássio (KF), gota a gota, obtendose um precipitado branco-translúcido de fluoreto de lítio, LiF, que foi filtrado, lavado com HF $0,01 \mathrm{~mol} \mathrm{~L}^{-1}\left(5 \mathrm{~mL} \mathrm{~g}^{-1}\right)$ e água a $10^{\circ} \mathrm{C}$ $\left(3 \mathrm{~mL} \mathrm{~g}^{-1}\right)$, e seco em estufa a $110^{\circ} \mathrm{C}$ por $2 \mathrm{~h}$. As águas de lavagem foram reunidas ao líquido final, o qual foi reaproveitado para novas aberturas da pilha em questão. A Figura 1 ilustra o fluxograma do processamento da pilha $\mathrm{Li} / \mathrm{MnO}_{2}$

pilha $\mathrm{Zn} / \mathrm{ar}$ : foi realizada a precipitação seletiva do íon $\mathrm{Hg}^{2+}$ pela adição de tioacetamida $\left(3 \mathrm{~mol} \mathrm{~L}^{-1}\right)$, gota a gota, em meio ácido ajustado a pH $0\left(\mathrm{com} \mathrm{NaOH} 12,5 \mathrm{~mol} \mathrm{~L}^{-1}\right)$, a $90{ }^{\circ} \mathrm{C}$, até cessar a formação do sulfeto $\mathrm{HgS}$. Esse precipitado, preto, foi centrifugado e lavado com água $\left(5 \mathrm{~mL} \mathrm{~g}^{-1}\right)$ e recentrifugado até $\mathrm{pH}$ da água de lavagem 7. Deve-se evitar um excesso de tioacetamida para que o zinco e o ferro presentes não precipitem como sulfetos nas etapas seguintes do fracionamento. $\mathrm{O}$ excesso foi destruído por adição de $\mathrm{H}_{2} \mathrm{O}_{2}$ a $90^{\circ} \mathrm{C}$ por $10 \mathrm{~min}$. Na seqüência, o ferro foi precipitado como hidróxido, $\mathrm{Fe}(\mathrm{OH})_{3}$, em $\mathrm{pH}$ próximo de 14 , por adição de $\mathrm{NaOH}$ $12,5 \mathrm{~mol} \mathrm{~L}^{-1}$. O zinco também foi isolado como hidróxido, $\mathrm{Zn}(\mathrm{OH})_{2}$, mediante neutralização com $\mathrm{H}_{2} \mathrm{SO}_{4} 9 \mathrm{~mol} \mathrm{~L}^{-1}$. Ambos os hidróxidos foram lavados com $\mathrm{NH}_{4} \mathrm{NO}_{3} 0,01 \mathrm{~mol} \mathrm{~L}^{-1}$ (até remoção dos íons $\mathrm{Na}^{+}$ e $\left.\mathrm{SO}_{4}{ }^{2-}-8 \mathrm{~mL} \mathrm{~g}^{-1}\right)$ e água $\left(3 \mathrm{~mL} \mathrm{~g}^{-1}\right)$, secos em estufa a $150{ }^{\circ} \mathrm{C}$ por 3 h e pesados. O líquido final neutralizado não continha coloração e sólidos em suspensão. O fluxograma do processo está representado na Figura 2.

pilha Ag-Zn: o esquema geral (Figura 3) é o mesmo aplicado à pilha $\mathrm{Zn}$-ar, com uma etapa adicional, que é a precipitação da prata. Ela foi isolada mediante adição de $\mathrm{NaCl} 0,5 \mathrm{~mol} \mathrm{~L}^{-1}$, gota a gota, até cessar a formação de precipitado branco de $\mathrm{AgCl}$, que foi filtrado, lavado com $\mathrm{HNO}_{3} 0,01 \mathrm{~mol} \mathrm{~L}^{-1}\left(7 \mathrm{~mL} \mathrm{~g}^{-1}\right.$, até eliminação dos íons $\left.\mathrm{Cl}^{-} \mathrm{e} \mathrm{SO}_{4}^{2-}\right)$ e com água até $\mathrm{pH} 7\left(3 \mathrm{~mL} \mathrm{~g}^{-1}\right)$, seco em estufa a $110^{\circ} \mathrm{C}$ por $2 \mathrm{~h}$ e pesado. Este procedimento foi efetuado antes da precipitação do $\mathrm{HgS}$, do contrário a prata co-precipitaria com o mercúrio.

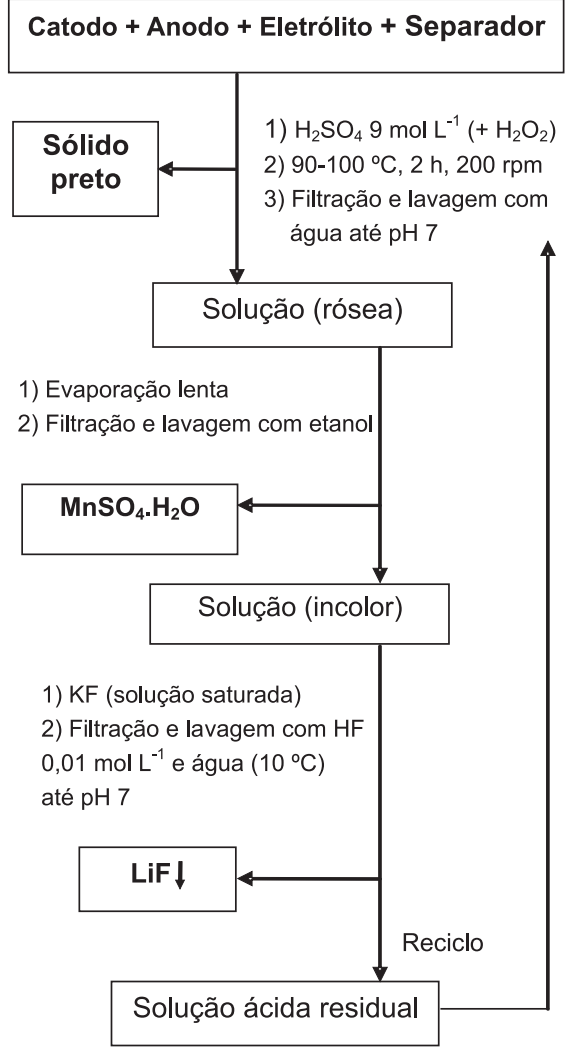

Figura 1. Fluxograma de abertura e fracionamento dos elementos presentes nos componentes internos da pilha $\mathrm{Li} / \mathrm{MnO}_{2}$ tipo botão

\section{Métodos analíticos}

Os metais em solução e isolados nas diversas etapas de fracionamento foram analisados por espectrometria de absorção atômica (instrumento Perkin Elmer AAS 3300), cujos limites de detecção, determinados experimentalmente, são: mercúrio: $0,1 \mathrm{mg} \mathrm{L}^{-1}$; prata: 0,2 $\mathrm{mg} \mathrm{L}^{-1}$; manganês, ferro e zinco, $0,5 \mathrm{mg} \mathrm{L}^{-1}$; lítio, $1 \mathrm{mg} \mathrm{L} \mathrm{L}^{-1}$. Empregou-se também a gravimetria para a determinação da massa dos resíduos insolúveis das aberturas e dos produtos finais obtidos. As dosagens quantitativas foram complementadas por análises qualitativas tradicionais ${ }^{9,27}$ nas soluções e nos sólidos. O solvente orgânico coletado das pilhas $\mathrm{Li} / \mathrm{MnO}_{2}$ foi analisado por infravermelho.

\section{RESULTADOS E DISCUSSÃO}

\section{Composição das pilhas botão}

O resíduo insolúvel após as aberturas ácidas corresponde ao carbono, presente no catodo dos produtos em estudo. A quantidade deste elemento nas pilhas $\mathrm{Zn} / \mathrm{ar}$ e $\mathrm{Ag}-\mathrm{Zn}$ foi, em média, $11 \% \mathrm{~m} / \mathrm{m}$ da massa total inicial, concordando com os dados da literatura (12-18\% $\mathrm{m} / \mathrm{m}^{2}$ ), enquanto que a pilha $\mathrm{Li} / \mathrm{MnO}_{2}$ possui uma quantidade muito menor, quando comparada àquela do formato já estudado anteriormente, ${ }^{26}$ apenas cerca de $2 \% \mathrm{~m} / \mathrm{m}$, contra $30 \%$ do estudo anterior. O resíduo de carbono inclui eventuais restos do separador anodo-catodo que não foi digerido com os ácidos minerais. A composição da pilha de $\mathrm{Li} / \mathrm{MnO}_{2}$ tipo botão (Tabela 1 ) é bem diferente daquela utilizada em câmaras digitais, ${ }^{26}$ onde o invólucro externo compõe menos de $10 \% \mathrm{~m} / \mathrm{m}$ do produto, enquanto que o catodo + anodo + eletrólito equivalem a $70 \% \mathrm{~m} / \mathrm{m}$. Isso se justifica pelo formato diferenciado das duas pilhas: o modelo botão é muito achatado e fino, de modo 


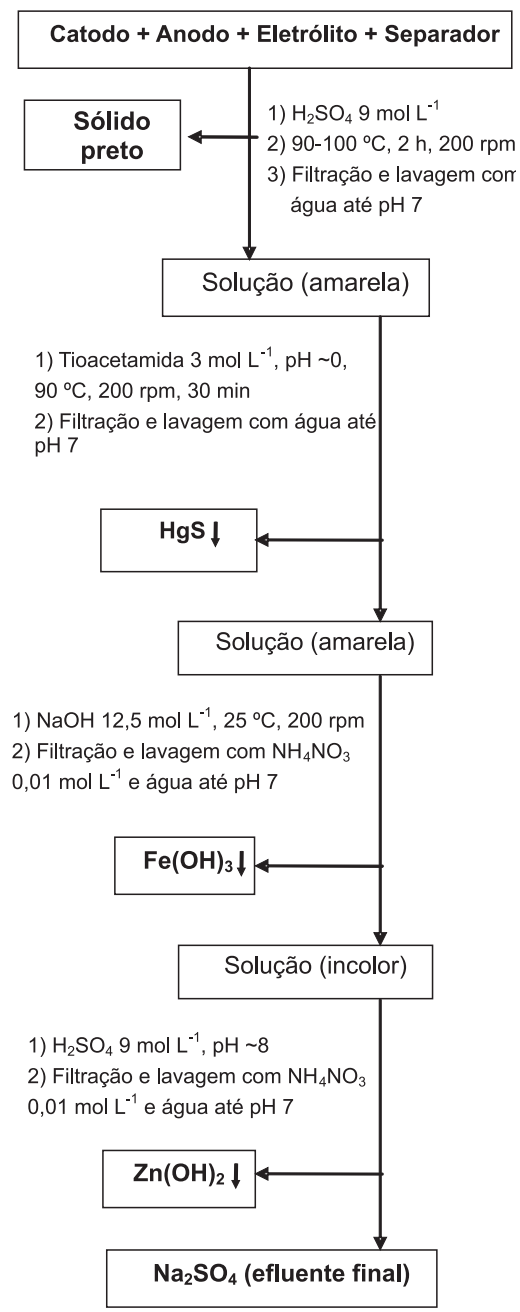

Figura 2. Fluxograma de abertura e fracionamento dos elementos presentes nos componentes internos da pilha Zn-ar tipo botão

que menos componentes internos se acham presentes em relação ao formato habitual. De acordo com testes qualitativos, o eletrólito presente é o LiPF 6 . O solvente não aquoso encontrado foi o carbonato de propileno. Estes dois resultados são os mesmos verificados nas pilhas $\mathrm{Li} / \mathrm{MnO}_{2}$ de câmaras digitais. ${ }^{26}$

No caso das pilhas Zn-ar e Ag-Zn, os componentes internos e o invólucro de aço têm participações quase iguais, fato esse de acordo com outras composições relatadas na literatura..${ }^{9,2} \mathrm{O}$ conteúdo interno de ambos os produtos tem um $\mathrm{pH}$ fortemente alcalino (em torno de 13), proveniente do $\mathrm{KOH}$ utilizado como eletrólito.

\section{Análise química das pilhas botão}

As análises por absorção atômica das soluções obtidas após a digestão ácida dos componentes internos (Tabela 2) indicam que a quantidade de metais presentes nas pilhas $\mathrm{Zn}$-ar e Ag-Zn concorda relativamente bem com dados da literatura, ${ }^{2,9,23,28}$ fato que não ocorre com as pilhas $\mathrm{Li} / \mathrm{MnO}_{2}$, por conta da menor participação dos componentes internos em relação ao produto tradicional; ${ }^{26}$ contudo, a razão mássica manganês/lítio é similar nos dois casos. O ferro aparece nas pilhas Zn-ar e Ag-Zn, especialmente na primeira, fruto da corrosão do invólucro externo de aço; como os componentes internos da pilha de $\mathrm{Li} / \mathrm{MnO}_{2}$ não são corrosivos, a corrosão do invólucro externo não se mostrou apreciável dentro do período entre o fim da vida útil e o processamento hidrometalúrgico.

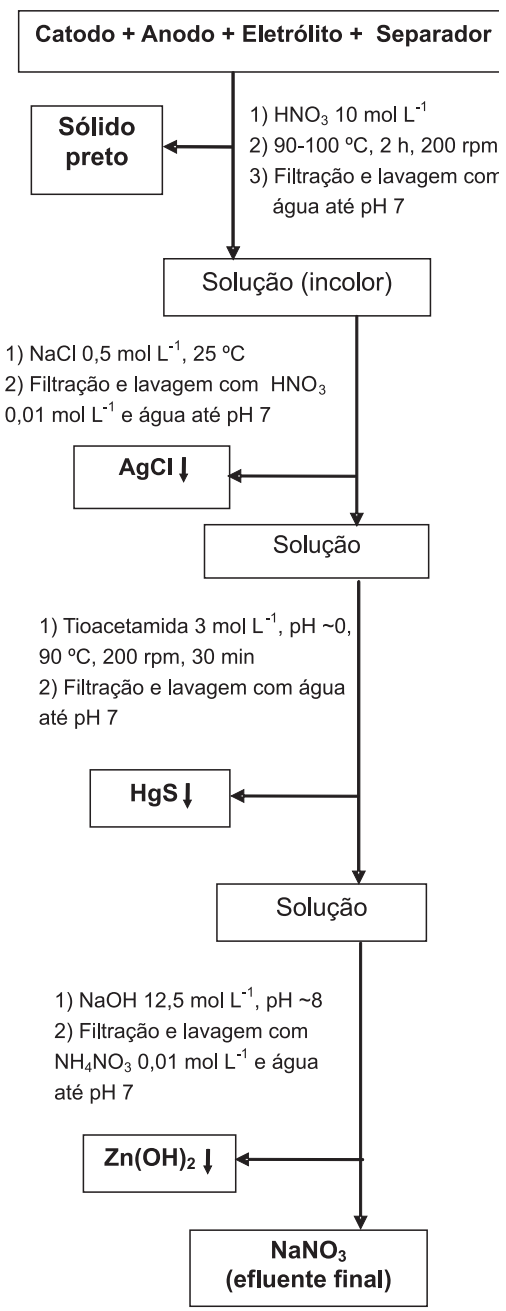

Figura 3. Fluxograma de abertura e fracionamento dos elementos presentes nos componentes internos da pilha Ag-Zn tipo botão

Com base na massa total das pilhas Zn-ar e Ag-Zn (1,6 a 2,2 g), a quantidade de mercúrio presente por pilha é da ordem de 15-17 mg, portanto abaixo do limite estabelecido pelas resoluções 257 e 263/99 do CONAMA ${ }^{17}(25 \mathrm{mg})$, o que permite que as mesmas sejam descartadas junto com o lixo urbano em aterros sanitários licenciados.

\section{Comportamento das rotas de processamento estudadas}

\section{Pilha de $\mathrm{Li} / \mathrm{MnO}_{2}$}

As rotas desenvolvidas em laboratório para as pilhas empregadas em câmaras digitais ${ }^{26}$ funcionaram bem para o modelo em estudo. O manganês foi recuperado em $93,2 \pm 1,5 \% \mathrm{~m} / \mathrm{m}$, e a pureza de seu sulfato era superior a $99 \% \mathrm{~m} / \mathrm{m}$. O lítio, recuperado como fluoreto, também tinha pureza superior a $99 \% \mathrm{~m} / \mathrm{m}$, e o metal alcalino foi recuperado em $49,7 \pm 0,6 \% \mathrm{~m} / \mathrm{m}$, sem a interferência do íon fosfato oriundo do eletrólito, provavelmente porque a participação deste na composição da pilha é muito baixa, de modo que o fosfato $\mathrm{Li}_{3} \mathrm{PO}_{4}$ não co-precipitou com o fluoreto. A solução ácida residual foi reciclada até 3 vezes sem perda de rendimento, o que se constitui numa vantagem ambiental porque menos resíduos de processo são gerados por massa de pilha processada.

\section{Pilhas de Zn-ar e Ag-Zn}

A opção de isolar a prata como cloreto mostrou-se muito eficiente. De acordo com os dados da Tabela 3, mais de 99,5\% $\mathrm{m} / \mathrm{m}$ do metal 
Tabela 1. Componentes das pilhas do tipo botão estudadas (valores expressos em $\% \mathrm{~m} / \mathrm{m}$ )

\begin{tabular}{lccc}
\hline Tipo de pilha & $\begin{array}{c}\text { Invólucro } \\
\text { externo }\end{array}$ & $\begin{array}{c}\text { Tela } \\
\text { metálica }\end{array}$ & $\begin{array}{c}\text { Catodo + anodo } \\
\text { + eletrólito } \\
+ \text { separador }\end{array}$ \\
\hline $\mathrm{Li} / \mathrm{MnO}_{2}{ }^{\mathrm{a}}$ & $62,2 \pm 3,4 \%$ & $1,3 \pm 0,7 \%{ }^{\mathrm{b}}$ & $36,1 \pm 2,9 \%$ \\
$\mathrm{Zn}-\mathrm{ar}$ & $54,5 \pm 1,7 \%$ & ausente & $45,5 \pm 2,9 \%$ \\
$\mathrm{Ag}-\mathrm{Zn}$ & $53,2 \pm 1,6 \%$ & ausente & $46,8 \pm 1,9 \%$ \\
\hline
\end{tabular}

a) Eventuais perdas de massa são devidas à evaporação do solvente. b) A tela metálica, feita de níquel, ${ }^{26}$ atua como coletor de corrente. Algumas das pilhas não apresentaram esta tela, segundo o fabricante considerado.

Tabela 2. Metais presentes $(\% \mathrm{~m} / \mathrm{m})$ nas pilhas do tipo botão estudadas

\begin{tabular}{lcccccc}
\hline Pilha & $\mathrm{Zn}$ & $\mathrm{Hg}$ & $\mathrm{Fe}$ & $\mathrm{Ag}$ & $\mathrm{Li}$ & $\mathrm{Mn}$ \\
\hline $\mathrm{Zn}-\mathrm{ar}$ & 30,2 & 0,9 & 3,5 & - & - & - \\
& $\pm 2,0$ & $\pm 0,1$ & $\pm 1,9$ & & & \\
$\mathrm{Ag}-\mathrm{Zn}$ & 10,4 & 0,8 & 0,5 & 29,5 & - & - \\
& $\pm 1,7$ & $\pm 0,2$ & $\pm 0,2$ & $\pm 1,3$ & & \\
$\mathrm{Li} / \mathrm{MnO}_{2}$ & - & - & $<0,5$ & - & 3,7 & 16,5 \\
& & & & & $\pm 0,3$ & $\pm 1,1$ \\
\hline
\end{tabular}

foi recuperado no precipitado de $\mathrm{AgCl}$, confirmando os resultados relatados na literatura. ${ }^{9} \mathrm{O}$ isolamento do mercúrio como sulfeto conformou a premissa de ser um excelente método de remoção do metal em solução: mais de $99,5 \% \mathrm{~m} / \mathrm{m}$ foi precipitado em todas as amostras processadas, tornando a manipulação da mistura reacional mais segura e permitindo uma destinação final dos resíduos bem menos complexa que na presença do referido metal.

A separação ferro-zinco por meio de precipitação seqüencial apresentou resultados bastante bons (Tabela 3), porém menos satisfatórios à medida que o ferro aumentava a sua concentração na solução. Isso significa que uma pilha $\mathrm{Zn}$-ar (ou de qualquer outro tipo) deve ser processada o mais rapidamente possível, de modo a isolar os componentes internos com uma menor contaminação possível de ferro por corrosão. Isso se justifica porque o invólucro externo tem uma participação na composição da pilha maior que os componentes internos. O principal problema do ferro é arrastar/ co-precipitar parte do zinco no momento de sua precipitação. Novas dissoluções dos hidróxidos impuros em ácido seguido de tratamento com $\mathrm{NaOH}(\mathrm{pH}>13)$ permitem alcançar a separação desejada com pureza elevada, mas isso implica em maior consumo de reagentes e insumos. $\mathrm{O}$ efluente final contém metais pesados em quantidades inferiores a 1 ppm, enquadrando-se para descarte segundo as normas da resolução 357/05 do CONAMA. ${ }^{29}$

O processamento das lixívias das pilhas Zn-ar e Ag-Zn é bastante similar, diferenciando-se principalmente pelo ácido usado na abertura dos componentes internos. Porém, é possível processar ambos os tipos de pilhas misturadas. Caso se empregue ácido nítrico, o fracionamento segue esta ordem: prata (Figura 3), mercúrio (Figura 2 ou 3), ferro (Figura 2) e zinco (Figura 2 ou 3). Se o ácido usado for o sulfúrico, a prata ficará junto com o sólido preto, e o restante do fracionamento segue o esquema da Figura 2. Este sólido preto pode ser calcinado em mufla $\left(600^{\circ} \mathrm{C}\right)$ sem acesso de ar (obtém-se prata metálica), ou tratado com ácido nítrico $10 \mathrm{~mol} \mathrm{~L}^{-1}$; após separação do sólido preto, obtém-se uma solução de $\mathrm{AgNO}_{3}$.

\section{CONCLUSÕES}

O processamento de pilhas do tipo botão mostrou-se relativamente simples devido à presença de poucos elementos na formulação desses produtos. $\mathrm{O}$ emprego dessa pilhas como um exemplo didático, face às dificuldades práticas verificadas nos procedimentos de reciclagem testados neste trabalho (incluindo práticas de higiene e segurança ocupacional) pode despertar nas pessoas uma maior consciência ambiental para que os produtos sejam projetados para serem mais facilmente recicláveis após o final de suas vidas úteis, acabando com a concepção utilitarista de um produto que cumpre apenas a sua finalidade, sendo descartado e substituído por um novo produto, sem qualquer preocupação com as consequiências ambientais desta atitude.

A prata, o manganês e o mercúrio foram isolados com excelentes rendimentos pela via tradicional de precipitação seletiva. Contudo, o ferro e o zinco apresentaram problemas com o avanço da corrosão do invólucro externo. A separação de um destes em meio ácido por extração por solventes resolveria a dificuldade observada quando do emprego de técnicas de precipitação, ao mesmo tempo em que se evitaria a necessidade de trabalhar em meio alcalino, significando uma grande redução no consumo de reagentes e insumos. Essa linha de trabalho se acha em curso hoje no laboratório, e já foi aplicada com sucesso ao caso do processamento de catalisadores gastos de hidrotratamento em meio de ácido sulfúrico. ${ }^{30}$ Outra estratégia é reciclar o mais rapidamente possível a pilha usada a fim de reduzir a introdução de ferro na massa a ser processada.

Além do processamento individual, as pilhas Zn-ar e Ag-Zn podem ser processadas juntas. Contudo, a pilha $\mathrm{Li} / \mathrm{MnO}_{2}$ não pode ser tratada junto com as demais, ainda que após lixívia dos componentes internos com ácido sulfúrico. A presença de ferro e zinco impediria a cristalização do sulfato $\mathrm{MnSO}_{4} \cdot \mathrm{H}_{2} \mathrm{O}$ sem contaminação por estes metais, e a recuperação do lítio como LiF. Desse modo, é necessária uma etapa de segregação prévia da pilha $\mathrm{Li} / \mathrm{MnO}_{2}$ das demais. Ela

Tabela 3. Pureza $(\% \mathrm{~m} / \mathrm{m})$ dos produtos finais das pilhas $\mathrm{Zn}$-ar e Ag-Zn e concentração de metais no efluente final

\begin{tabular}{lcccccc}
\hline Elemento & Pilha & $\mathrm{HgS}$ & $\mathrm{Fe}(\mathrm{OH})_{3}{ }^{*}$ & $\mathrm{Zn}(\mathrm{OH})_{2}{ }^{*}$ & $\begin{array}{c}\text { AgCl } \\
\text { Efluente final } \\
\left(\mathrm{mg} \mathrm{L}^{-1}\right)\end{array}$ \\
\hline $\mathrm{Hg}$ & $\mathrm{Zn}-\mathrm{ar}$ & $99,8 \pm 0,2$ & $<0,1$ & $<0,1$ & ausente & $<0,1$ \\
$\mathrm{Zn}$ & $\mathrm{Ag}-\mathrm{Zn}$ & $99,7 \pm 0,1$ & $<0,1$ & $<0,1$ & $<0,1$ & 0,1 \\
& $\mathrm{Zn}-\mathrm{ar}$ & $<0,1$ & $0,9 \pm 0,3$ & $99,0 \pm 1,0$ & ausente & 0,1 \\
$\mathrm{Fe}$ & $\mathrm{Ag}-\mathrm{Zn}$ & $<0,1$ & $0,2 \pm 0,1$ & $99,6 \pm 0,5$ & $<0,1$ & $<0,1$ \\
& $\mathrm{Zn}-\mathrm{ar}$ & $<0,1$ & $97,8 \pm 1,2$ & $0,5 \pm 0,2$ & ausente & $<0,5$ \\
$\mathrm{Ag}$ & $\mathrm{Ag}-\mathrm{Zn}$ & $<0,1$ & $99,2 \pm 1,0$ & $0,2 \pm 0,1$ & $<0,1$ & ausente \\
& $\mathrm{Zn}-\mathrm{ar}$ & ausente & ausente & ausente & $<9,7 \pm 0,4$ & $<0,2$ \\
\hline
\end{tabular}

* Após duas redissoluções e reprecipitações, os teores de ferro no produto final de zinco, e deste no produto final de ferro, foram reduzidos a valores inferiores a $0,1 \% \mathrm{~m} / \mathrm{m}$. 
pode ser feita com relativa facilidade: a identificação desta pilha é impressa num dos lados do produto (3 V lithium battery).

\section{AGRADECIMENTOS}

C. N. da Silva agradece ao PIBIC/CNPq/UFRJ a concessão de bolsa de Iniciação Científica; a J. F. Paulino pela ajuda prestada na parte inicial desta pesquisa e ao CNPq pelo auxílio financeiro.

\section{REFERÊNCIAS}

1. Battery Application Manual, Eveready Battery Co. Inc.: St. Louis, 2001.

2. http://www.epbaeurope.net/batterymarket.html, acessada em Abril 2007.

3. Mohamad, A. A.; J. Power Sources 2006, 159, 752.

4. http://support.radioshack.com/support_tutorials/batteries/bt-zair-main. htm, acessada em Abril 2007.

5. Smith, D. F.; Gucinski, J. A.; J. Power Sources 1999, 80, 66.

6. Karpinski, A. P.; Makovetski, B.; Russell, S. J.; Serenyi, J. R.; Williams, D. C.; J. Power Sources 1999, 80, 53.

7. Karpinski, A. P.; Russell, S. J.; Serenyi, J. R.; Murphy, J. P.; J. Power Sources 2000, 91, 77.

8. Jin, X.; Lu, J.; J. Power Sources 2002, 104, 253.

9. Sathaiyan, N.; Nandakumar, V.; Ramachandran, P.; J. Power Sources 2006, 161, 1463.

10. Broussely, M.; Archdale, G.; J. Power Sources 2004, 136, 386.

11. The US Environmental Protection Agency, Office of Solid Waste; Implementation of the Mercury-Containing and Rechargeable Battery Management Act (EPA530-K-97-009), novembro 1997.

12. http://www.rbrc.org/call2recycle/index.html, acessada em Abril 2007.

13. http://www.epbaeurope.net/recycling.html, acessada em Abril 2007.

14. http://www.mte.gov.br/legislacao/normas_regulamentadoras/nr_15.pdf, acessada em Abril 2007.
15. Contestabile, M.; Panero, S.; Scrosati, B.; J. Power Sources 2001, 92, 65 .

16. Lee, C. K.; Rhee, K. I.; Hydrometallurgy 2003, 68, 5.

17. Resolução $N^{\circ} 257$, do Conselho Nacional do Meio Ambiente, 30 de junho de 1999, Diário Oficial da União, 22 de julho de 1999; Resolução No 263, do Conselho Nacional do Meio Ambiente, 12 de novembro de 1999, Diário Oficial da União, 12 de novembro de 1999. $\mathrm{O}$ andamento dos trabalhos do grupo de revisão desta resolução pode ser acompanhado no Portal http://www.mma.gov.br/port/conama/processo. cfm?processo=02000.005624/1998-07.

18. http://www.abinee.org.br/programas/prog02.htm, acessada em Abril 2007.

19. Testud, F.; Descotes, J.; Arch. Pédiatrie 2001, 8, 669.

20. Lin, V. Y. W.; Daniel, S. J.; Papsin, B. C.; Int. J. Pediatr. Otorhi. 2004, 68, 473.

21. Bartlett, D.; J. Emerg. Nurs. 2006, 32, 189.

22. Litovitz, M. D. T.; Butterfield, A. B.; Holloway, R. R.; Marion, L. I.; J. Pediatr. 1984, 105, 868.

23. Rebhandl, W.; Steffan, I.; Schramel, P.; Puig, S.; Paya, K.; Schwanzer, E.; Strobl, B.; Horcher, E.; J. Pediatr. Surg. 2002, 37, 87.

24. http://www.bbma.co.uk, acessada em Abril 2007.

25. Feigl, F.; Spot Tests In Inorganic Analysis, Elsevier: Amsterdam, 1958, cap. 3.

26. Paulino, J. F.; Busnardo, N. G.; Afonso, J. C.; Quim. Nova 2007, 30, 718.

27. Lurie, J.; Handbook of Analytical Chemistry, Mir: Moscou, 1978, cap. 3, 6 e 10.

28. Oliveira, M. B. O.; A Problemática do Descarte de Baterias Usadas no Lixo Urbano, Fundacentro: São Paulo, 2001.

29. Resolução $\mathrm{N}^{\circ}$ 357, do Conselho Nacional do Meio Ambiente, 17 de março de 2005, Diário Oficial da União, 18 de março de 2005.

30. Valverde Jr., I. M.; Paulino, J. F.; Afonso, J. C.; Quim. Nova 2008, 31, 680. 